\section{Acknowledgments}

Many individuals and institutions have contributed to the research carried out on majolica ceramics. We want to thank Richard Alhborn (Smithsonian Institution), whose interest and encouragement brought the topic to our attention. We also thank Florence Lister, David Hurst Thomas, Kathleen Deagan, and Stanley South for providing ceramic samples for these studies. We remember and gratefully acknowledge the contributions of Charles Fairbanks and Robert Lister. Numerous contributors to the research have authored papers which are included in the references. These include M. James Blackman (Smithsonian Institution), Marino Maggetti (University of Fribourg), Albert Jornet (Beinwil am See, Switzerland), Emile Joel (Smithsonian Institution), Bonnie McEwan (San Luis Archaeological and Historic Site), Fernando Amores (University of Seville), and Alfonso Plezguezuelo (University of Seville).

The research was supported by the Conservation Analytical Laboratory, the U.S.Spain Joint Committee for Cultural and Educational Cooperation, and the Smithsonian Institution's Scholarly Studies Program. Neutron activation analysis was carried out at Brookhaven National Laboratory under contract with the U.S. Department of Energy during the 1970s. More recent neutron activation analysis and lead isotope analysis have been conducted at the National Institute of Standards and Technology (NIST). At NIST, analysis was car- ried out with support of personnel from the Nuclear Methods Group and the Mass Spectrometry Group of the Division of Inorganic Analytical Chemistry and Reactor Operations.

\section{References}

1. F.C. Lister and R.H. Lister, Sixteenth Century Majolica Pottery in the Valley of Mexico, (University of Arizona Press, Tucson, Arizona, 1982)

2. F.C. Lister and R.H. Lister, Andalusian Ceramics in Spain and New Spain, (University of Arizona Press, Tucson, Arizona, 1987).

3. J.E. Myers, F. Amores, J.S. Olin, and A Pleguezuelo, Historical Archaeology 26 (1) (1992) in press.

4. J. Lorenzo, M. Vera, and C. Escudero, Anuario Arqueologico de Andalucia (Consejeria de Cultura de la Junta de Andalucia, 1987) p. $574-580$.

5. Lister, see Reference 2, p. 256

6. Albert Jornet "Provenance and Technological Investigations of Spanish and Spanish Colonial Majolica", unpublished manuscript on file at the Conservation Analytical Laboratory.

7. C. Gonzalez-Vilchez, G. Garcia-Ramos, F. Gonzalez-Garcia, and M. Pellicer-Catalan, Proceedings of the 22nd Symposium on Archaeometry (University of Bradford, 1983) p. 388-404.

8. Lister, see Reference 2, p. 160

9. B. Kleinmann, Proceedings of the 24th International Archaeometry Symposium, edited by J.S. Olin and M.J. Blackman (Smithsonian Institution Press, Washington, DC, 1986) p. 73.

10. A. Jornet, M.J. Blackman, and J.S. Olin, Ceramics and Civilization: Ancient Technology to Modern Science, edited by D. Kingery, (American Ceramic Society, Columbus, Ohio, 1985) p. 235 .

11. lbid., p. 253

12. J.M. Goggin, Spanish Majolica in the New World: Types of the Sixteenth to Eighteenth Centuries (Yale University Press, New Haven, 1968). 13. C. Fortnum, E. Drury, Majolica, London, n.d.

14. E. Rosenthal, Pottery and Ceramics from Common Brick to Fine China, London (1949).

15. C.F. Binns, Potter's Craft (Van Nostrand, Princeton, 1967).

16. W.W. Perkins, Ceramic Glossary (American Ceramic Society, Columbus, Ohio, 1984) p. 38.

17. E.A. Cervantes, Loza blanca y azulejo de Puebla, 2 vols., Mexico City (1939).

18. Lister, see Reference 2 , p. 265.

19. J.S. Olin, G. Harbottle, and E.V. Sayre, Archaeological Chemistry II, edited by G.F. Carter (American Chemical Society, Washington, DC, 1978) p. 200

20. J.E. Myers, F. Amores, J.S. Olin, and A. Pleguezuelo, Historical Archaeology 26 (1) (1992) in press.

21. M. Maggetti, H. Westley, and J.S. Olin, Archaeological Chemistry III, edited by J.B. Lambert (American Chemical Society, Washington, DC, 1984) p. 151

22. Kathleen Deagan, Artifacts of the Spanish Colonies of Florida and the Caribbean, 1500-1800

(Smithsonian Institution Press, Washington, DC, 1987)

23. J.S. Olin and M.J. Blackman, Archaeological Chemistry IV, edited by R.O. Allen (American Chemical Society, Washington, DC, 1989) p. 87. 24. Maggetti, see Reference 21, p. 169.

25. E.C. Joel, J.S. Olin, and M.J. Blackman, Proceedings of the 26th International Archaeometry Symposium (University of Toronto, 1988), p. 188. 26. R.K. Skowronek, Historical Archaeology 21 (2) (1987) p. 101.

\title{
Greater Pittsburgh Section Hosts Lecture on Smart Materials
}

On November 13, members and guests of the MRS Greater Pittsburgh Section were treated to an informative, entertaining lecture on "Smart Materials" by Dr. Robert Newnham, who will soon celebrate his 25th anniversary as Alcoa Professor of Solid State Science at the Pennsylvania State University.

After defining smart materials as those that can respond actively to some type of input, Newnham focused on the role of piezoelectric and magnetostrictive ceramics in various applications. These materials already perform several functions in automobiles; an example is the shock absorber in Toyota's new Lexus. In underwater communications, Newnham showed how technologists have studied the natural "talking" and "listening" mechanisms observed in fish and have imitated these de- signs to fabricate a class of biomimetic materials for potential use in Naval communication and fish farming. He concluded by pointing out needs in the medical and residential markets that can be filled by smart materials, showing the growth potential for this segment of the advanced materials arena.

Interest and participation in the activities of the Greater Pittsburgh Section has grown since the group was organized about two years ago, as shown by the turnout of about 75 scientists, engineers, and students for Newnham's lecture. The section officers, Deborah Partlow of Westinghouse STC, Pradeep Phule of the University of Pittsburgh, Michael McHenry of Carnegie Mellon University, and John Basil of PPG's Glass Research Center, have welcomed the contributions of three board members at large since the spring of 1991: Prashant Kumta, assistant professor in the Mechanical Engineering and Materials Science Department at Carnegie Mellon Universit; Devki Talwar, associate professor in the Physics Department at the Indiana campus of the University of Pennsylvania; and S.G. Sankar, senior scientist in the Data Storage Systems Center at Carnegie Mellon Research Institute. Sankar is also adjunct professor in the Mechanical Engineering and Materials Science Department at Carnegie Mellon University and executive vice president of the Advanced Materials Corporation. New officers for the Greater Pittsburgh Section will be elected in February 1992. 